\title{
Pengembangan Pendidikan Islam Integratif di Indonesia; Kajian Filosofis dan Metode Implementasi
}

\author{
Fiska Ilyasir ${ }^{1}$ \\ Universitas Alma Ata Yogykarta \\ email : f.ilyasir@gmail.com
}

\begin{abstract}
This paper attempts to discuss development of an integrated system of Islamic education in Islamic educational institutions in Indonesia. After reviewing some problems around the Islamic education as well as alternative solutions, the authors conclude that Islamic educational institutions must resolve the issues of dichotomy, and also that related to the vision and purposes of their institutions, internally and independently, which are an effort in dealing with many changes in modern society.

Islamic educational institutions must develop a new design of an integrated Islamic education. Along with this redesigning process, all the steps are expected to be a solution for the problem, including reviewing the philosophical foundation of the institutions, integrating Islamic values into the learning process, and also it's implementation.

On the philosophical level, educational institutions should revitalize their institutional goals, so that it will be a reference for the institution to implement the educational process. Whereas in the implementation stage, the institution must carry out these integration of Islamic education to the learning system, including the learning objectives, materials, human resources, or the environment.
\end{abstract}

Keyword: Islamic Education. Integrated Education, Dichotomy

\begin{abstract}
Abstrak
Tulisan ini mencoba untuk membahas pengembangan sistem pendidikan Islam terintegrasi di lembaga pendidikan islami di Indonesia. Setelah mengkaji problematika pendidikan Islam serta alternatif solusi yang mungkin dapat memecahkan permasalahan tersebut, penulis menyimpulkan bahwa dalam mengatasi perubahan masyarakat modern, secara internal dan mandiri, lembaga pendidikan Islam harus mampu menyelesaikan isu-isu dikotomi, dan juga yang terkait tujuan dan fungsi kelembagaannya.

Lembaga-lembaga pendidikan Islam harus mengembangkan sebuah desain baru pendidikan Islam terintegrasi. Beberapa langkah redesain yang diharapkan dapatmenjadi solusi permasalahan ini meliputi pengkajian ulang landasan filosofis lembaga pendidikan, pengintegrasian nilai-nilai Islam ke dalam proses pembelajaran, serta metode implementasi hasil redesain tersebut.

Pada tataran filosofis, lembaga pendidikan harus merevitalisasi tujuan kelembagaan mereka, sehingga dapat menjadi acuan untuk memperkuat landasan untuk proses pendidikan yang akan dilakukan. Sedangkan pada tataran implementasi, pengintegrasian pendidikan Islam harus dilaksanakan dalam seluruh sistem pembelajaran, entah pada level tujuan, materi, sumber daya manusia, ataupun lingkungan.
\end{abstract}

Kata Kunci pendidikan Islam, integrasi, dikotomi

${ }^{1 *}$ Dosen Program Studi Pendidikan Agama Islam (PAI) Fakultas Agama Islam Universitas Alma Ata Yogyakarta. 


\section{PENDAHULUAN}

Saat ini pendidikan tidak lagi dipandang sebagai bentuk pemuasan atas kebutuhan yang bersifat sementara. Lebih dari itu, pendidikan merupakan sebuah human investment yang dianggap mampu meningkatkan produktivitas manusia sehingga dapat meningkatkan daya jual dan daya saing di masa yang akan datang. Pendidikan juga menjadi windows of opportunity yang akan memberikan pengaruh secara tidak langsung kesadaran akan pemerataan kesempatan memperoleh pendidikan.

Pergeseran paradigma dalam melihat kondisi kehidupan di masa depan yang semula dianggap relatif stabil menjadi unpredictable. Maka, menurut Djamaluddin Ancok, Desain pendidikan Islam saat ini tidak bisa lagi bersifat linier, tetapi harus direformasi menjadi sebuah desain yang bersifat lateral dalam menghadapi perubahan yang begitu massif dan tidak terpolakan. Atas dasar itu, sebagaimana yang disimpulkan Djamaluddin Ancok, pendidikan harus mempersiapkan empat modal untuk menghadapi tantangan tersebut, yakni modal intelektual, modal sosial, modal lembut, dan modal spiritual. Tantangan perubahan paradigma ini tentu tidak semudah membalik telapak tangan. ${ }^{2}$

Kondisi dan Perkembangan Pendidikan Islam di Indonesia dapat dikatakan masih tertinggal dari tuntutan masyarakat modern. Arus globalisasi millenium ketiga yang masuk ke Indonesia disertai budaya luar yang sangat beragam menjadi tantangan sendiri bagi masyarakat muslin di negara ini. Mau tidak mau, pendidikan Islam sebagai salah satu pranata sosial dituntut untuk memiliki tujuan yang tidak hanya mampu mengantarkan peserta didik untuk bahagia di akhirat, namun juga tujuannya harus meliputi dimensi ortopraksis. ${ }^{3}$

${ }^{2}$ Djamaluddin Ancok, Membangun Kompotensi Manusia dalam Milenium Ke Tiga, Psikologika, Jurnal Pemikiran dan Penelitian Psikologi, Nomor: 6 Tahun III, (Yogyakarta: UII Press, 1998) hlm. 5.

${ }^{3}$ Moh. Shofan, Pendidikan Berparadigma Profetik; Upaya Konstruktif Membongkar Dikotomi Sistem Pendidikan Islam, (Yogyakarta; IRCISoD, 2004), hlm. 27
Secara historis, pendidikan Islam di Indonesia telah ada sejak berabad lalu. Sejak dari awal masuknya agama Islam ke Indonesia hingga terbentuknya lembaga-lembaga pendidikan formal seperti madrasah-madrasah yang ada pada saat ini. Berbagai upaya juga telah dilakukan pemerintah untuk meningkatkan kualitas pendidikan Islam di negara kita ini, dari SKB tiga menteri pada tahun 1975 hingga masuknya madrasah sebagai sub-sistem pendidikan nasional sejak diberlakukannya Undang Undang Sistem Pendidikan Nasional tahun 1989. Namun, secara umum lembagalembaga pendidikan Islam kita masih belum bisa melaksanakan tugas mereka sebagai salah satu pranata sosial masyarakat.

Salah satu dampak yang muncul dari besarnya masalah pendidikan Islam di Indonesia adalah terjadinya dikotomi pendidikan. Hal ini ditengarai oleh para ahli sebagai gejala dari belum kokohnya tujuan dan fungsi lembaga pendidikan Islam, serta persoalan implementasi kurikulum, termasuk penyusunan materi pendidikan. Ketiga persoalan ini saling terkait antara satu dengan lainnya. ${ }^{4}$ Dalam paper ini penyusun akan mencoba untuk membahas masalah-masalah yang dihadapi pendidikan Islam tersebut beserta alternatif solusi sebagai bahan masukan perbaikan dan kemajuan pendidikan Islam di Indonesia dan kesiapannya untuk ikut bersaing dalam percaturan dunia modern.

\section{PENDIDIKAN ISLAM DI INDONESIA DAN PERMASALAHANNYA}

Pendidikan Islam yang dimaknai sebagai upaya untuk mewariskan nilai- nilai ajaran dan budaya Islam kepada generasi penerus, masih terkendali pada persoalan dualisme sistem pendidikannya. Pendidikan Islam saat ini terkungkung bahkan disimpulkan sedang terjebak dalam kemunduran, keterbelakangan, dan ketidakberdayaan sebagaimana yang dialami oleh sebagian besar negara dan masyarakat muslim. Bahkan, pendidikan yang

${ }^{4}$ Hujair Sanaky, Studi Pemikiran Pendidikan Islam Modern, http://www.sanaky.com/ diakses pada 11 Oktober 2016. 
diberi suffix Islam, juga dianggap berkonotasi kemunduran, meskipun saat ini secara perlahan banyak lembaga pendidikan Islam yang telah membuktikan kesuksesan dalam pengembangan kelembagaan.

Justifikasi ini memberikan dampak yang kuat terhadap sistem pendidikan Islam di Indonesia. Akhirnya lembaga pendidikan Islam dipandang inferior dalam tatanan sistem pendidikan negara kita, walaupun dalam undang-undang sistem pendidikan nasional disebutkan bahwa pendidikan Islam merupakan sub-sistem pendidikan nasional. Menyikapi hal ini, Muchtar Buchori menyatakan bahwa walaupun hal ini tidak dapat dipandang sebagai bukti definitif, namun tidak bisa dipungkiri bahwa hal ini merupakan realita yang dihadapi lembaga pendidikan Islam di Indonesia.

Undang-undang Sistem Pendidikan Nasional Indonesia menyebutkan bahwa pendidikan Islam merupakan sub-sistem dari Pendidikan Nasional. Namun pada kenyataannya pendidikan Islam belum bisa dikatakan memiliki kesempatan yang sama untuk bersaing dan berkiprah dalam membangun masyarakat Indonesia yang besar. Merupakan sebuah permasalahan yang cukup serius apabila dalam sebuah komunitas muslim yang sangat besar, justru perhatian pemerintah terhadap pendidikan Islam yang dicurahkan sangat kecil. Padahal, berdasarkan apa yang menjadi tujuan pendidikan Nasional Indonesia, generasi Indonesia diharapkan menjadi masyarakat sosialistik religius. ${ }^{5}$

Pendidikan Islam di Indonesia secara umum dapat dikatakan masih belum mengalami perkembangan yang berarti. Tantangan dan permasalahan yang dihadapi masih sangat kompleks, sehingga pengembangan dan inovasi pendidikan Islam masih menjadi pekerjaan rumah yang harus terus dilakukan. Walaupun demikian dalam tahun-tahun terakhir secara bertahap telah menunjukkan proses kemajuan. Hal ini ditunjukkan dengan berdirinya beberapa lembaga pendidikan Islam dengan model pendidikan yang dicoba untuk dikembangkan.

${ }^{5}$ Muslih Usa, Pendidikan Islam di Indonesia; Antara Cita dan Fakta, (Yogyakarta: Tiara Wacana, 1991), hlm. 11
Oleh karena itu, pendidikan Islam dituntut untuk terus berinovasi dalam pengembangan dirinya. Baik dari sisi kurikulum, perangkat manajemen, baik dari sisi pengembangannya maupun strategi dan taktik operasionalnya sehingga lebih efektif dan efisien, baik dalam secara pedagogik, maupun sosio-cultural. ${ }^{6}$

Dari berbagai persoalan yang menimpa pendidikan Islam di Indonesia, masalah yang cukup serius dan perlu segera dipecahkan adalah dikotomi keilmuan antara ilmu "agama" dan ilmu "umum". Problematika ini kemudian termanifestasikan secara kelembagaan ke dalam dua model sistem pendidikan di Indonesia, yaitu "sekolah" yang berada di bawah naungan Kementerian Pendidikan dan Kebudayaan dan "madrasah" yang berada di bawah naungan Kementerian Agama Republik Indonesia.

Tertanamnya prinsip dikotomis dalam sistem pendidikan di Indonesia menurut Prof. Dr. Syafi'i Ma'arif adalah merupakan suatu tanda tidak kuatnya landasan filosofis pendidikan di Indonesia. Hal ini kemudian memunculkan suatu kesan, bahwa Islam semata-mata sebagai sistem ideologi. ${ }^{7}$

Selain dari pada itu, problem yang nampak terlihat dalam diskursus ilmu pendidikan Islam adalah masih belum terakumulasinya bidangbidang garapan pendidikan Islam untuk menjadi suatu disiplin ilmu tersendiri. Sudah selayaknya pendidikan Islam telah memproyeksikan ilmu yang ilmiah dan alamiah, sehingga dapat berfungsi sebagai sarana Pemberdayaan manusia (impowerment of people) yang benarbenar bernafaskan Islam. ${ }^{8}$

Secara umum, Moh. Shofanmengemukakan bahwa dikotomi sistem pendidikan di dunia muslim disebabkan oleh tiga faktor utama, yaitu kejumudan pemikiran di dunia Islam, Kolonialisasi barat terhadap dunia muslim, dan Modernisasi dunia Islam itu sendiri.

Terkait faktor kejumudan pemikiran di dunia Islam, Shofan menyatakan bahwa

${ }^{6} \mathrm{HM}$. Arifin, Kapita Selekta Pendidikan, (Jakarta: Bina Aksara, 1991) hlm. 3

${ }^{7}$ Ahmad Warid Khan, Membebaskan Pendidikan Islam, (Yogyakarta: Wacana, 2002), hlm. 111

${ }^{8}$ Ibid., hlm. 112 
stagnasi pemikiran ini dikaitkan dengan kemandekan keilmuan yang melanda peradaban umat Islam yang terjadi pada abad ke-16 hingga abad ke-17 M. Kejumudan ini merupakan imbas dari kemunduran di bidang politik dan budaya. Pada saat itu, Umat muslim saat itu terperosok pada romantisme masa lalu. Mereka cenderung melihat kejayaan mere pada abad pertengahan. Sehingga para sarjana barat mengatakan bahwa romantisme masa lalu itu membuat para sarjana muslim tidak menanggapi tantangan baru yang nyata. Dunia muslim saat melewatkan kesempatan mereka untuk dapat mengasimilasikan ilmu pengetahuan yang berkembang untuk kemudian memberinya warna baru. ${ }^{9}$

Faktor Kedua, sebagaimana tercatat dalam sejarah, penjajahan barat atas dunia muslim berlangsung sejak abad 18 hingga abad 19 M. Dunia muslim saat itu sama sekali tidak berdaya menghadapi hegemoni imperialisme Barat. Kondisi seperti itu tentu memberikan keleluasaan bagi kaum imperialis untuk melakukan penetrasi budaya dan peradaban modern barat. Karenanya pendidikan budaya barat mampu mendominasi dan menekan struktur budaya setempat yang dibangun sejak lama. Sistem pendidikan barat menggantikan sistem pendidikan "tradisional" yang dimiliki kaum muslim, sehingga menurunkan derajat "ilmu agama" dan menjadikan "pengetahuan barat" sebagai mata pelajaran utama di lembagalembaga pendidikan, bahkan di lembaga pendidikan Islam.

Lebih jauh lagi, integrasi keilmuan menjadi terlupakan dan bahkan tidak dipertahankan. Faham bahwa kajian keilmuan harus dipisahkan dari kajian keagamaan terus dikembangkan oleh Barat. Sehingga di dunia muslim juga berkembang hal yang sama, yakni kajian ilmu dan teknologi harus terpisah dari kajian agama. ${ }^{10}$

Lebih jauh tentang faktor historis ini, Azyumardi Azra sebagaimana dikutip oleh Muliawan menyebutkan bahwa bifurkasi keilmuan ini merupakan buah dari kecelakaan hlm. 111

${ }^{9}$ Moh. Shofan, Pendidikan Berparadigma...,

${ }^{10}$ Ibid, hlm. 111-112. sejarah (historical accident). Yaitu ketika ilmuilmu "modern" yang dibangun atas dasar data empiris, rasio, dan logika mengalami resistensi yang hebat dari para agamawan. ${ }^{11}$

Azyumardi Azra juga menyatakan lebih jauh bahwa dikotomi keilmuan sangat terkait dengan situasi objektif pendidikan Islam yang mengalami krisis konseptual pada tataran epistemologisnya, sehingga terjadinya pemisahan bidang ilmu di dalam Islam. Kita kemudian mendengar istilah ilmu dunia (general sciences) yang bersifat profane, dan kemudian dihadapakan dengan ilmu-ilmu agama (al'umum al-diniyyah / religious sciences) yang dianggap sakral (transenden). ${ }^{12}$

Terakhir, Selain imperialisme Barat yang terjadi di masa lalu, Moh. Shofan menyebutkan bahwa modernisasi dunia Islam sendiri telah memberikan andil dalam mempertajam bifurkasi keilmuan dan sistem pendidikan di negaranegara berpenduduk muslim. Modernisasi muncul sebagai suatu perpaduan antara ideologi Barat, Teknikisme dan Nasionalisme. Teknikisme muncul sebagai suatu reaksi terhadap dogma, sedangkan Nasionalisme ditemukan di Eropa dan didoktrinkan secara paksa kepada Umat Islam. ${ }^{13}$

Krisis inilah yang terjelma dalam konteks kebangsaan kita dengan terbangunnya dualisme sistem Pendidikan Nasional Indonesia. ${ }^{14}$ Berkembangnya dikotomi keilmuan ini tentu memberikan dampak negatif pada dunia Pendidikan Islam, termasuk di Indonesia. Beberapa efek negatif yang muncul dari bifurkasi sistem pendidikan antara lain: Pertama Munculnya ambivalensi orientasi pendidikan Islam. Pertentangan orientasi ini memunculkan kebingungan di kalangan Umat Islam. Hal menjadikan umat Islam membatasi diri untuk mengkaji bidang keilmuan yang dianggap

${ }^{11}$ Azyumardi Azra, Esei-esei Intelektual Muslim dan Pendidikan Islam (Jakarta: Logos Wacana Ilmu, 1998), 94

${ }^{12}$ Azyumardi Azra, Paradigma Baru Pendidikan Nasional, Rekontruksi dan Demokratisasi, (Jakarta : Kompas, 2006), hlm. 217

${ }^{13}$ Moh. Shofan, Pendidikan Berparadigma..., hlm. 111

${ }^{14}$ Ibid, hlm. 114. 
ambigu. Ambivalensi ini juga menjadi salah satu pemicu pandangan dikotomis terhadap ilmu pengetahuan. ${ }^{15}$ Pandangan ini jelas bertentangan dengan konsep ajaran Islam itu sendiri. Islam memiliki ajaran yang bersifat integralstik. Yaitu bahwa urusan dunia tidak terpisah dengan urusan akhirat.

Kedua, dikotomi keilmuan dapat memicu disintegrasi sistem pendidikan Islam itu sendiri. Boleh dikatakan, bahwa saat ini sistem pendidikan di Indonesia kurang terjadi proses integrasi keilmuan. Hal ini kemudian diperparah dengan kesenjangan dan ketidakpastian hubungan antara pendidikan umum dan pendidikan agama, baik secara keilmuan, maupun kelembagaan. Ketidakjelasan ini terwujud dalam kesenjangan antara kompetensi guru agama dan capaian pembelajaran yang dibutuhkan anak didik, terutama di sekolah umum. Dampak yang lebih jauh lagi, maka dikotomi keilmuan ini akan terus diwariskan dari generasi ke generasi, apabila tidak ada upaya untuk menghentikannya.

Terakhir, bifurkasi keilmuan menumbuhkan sifat Inferioritas para pengasuh lembaga pendidikan Islam. Pengembangan lembaga pendidikan Islam masih diwarnai pandangan bahwa sistem pendidikan barat adalah acuan modernitas. Cara pandang semacam ini senantiasa memunculkan pendekatan dengan suatu hipotesis defisit. Sistem pendidikan Islam dipandang sebagai sosok terbelakang. ${ }^{16}$

\section{PENDIDIKAN ISLAM INTEGRATIF SEBAGAI PEMBENTUK MASYARAKAT MUSLIM INDONESIA MODERN}

Perubahan tatanan sosial dan asimilasi kebudayaan yang terjadi di masyarakat Indonesia, menuntut lembaga pendidikan Islam untuk mampu menghadirkan lembaga pendidikan Islam yang relevan dengan perubahan dan perkembangan tersebut. Redesain kelembagaan tersebut juga diharapkan dapat diintegrasikan ke dalam kehidupan masyarakat

\footnotetext{
${ }^{15}$ Kuntowijoyo, Paradigma Islam: Interpretasi Untuk Aksi (Bandung: Mizan, 1991), hlm. 352 hlm. 116

${ }^{16}$ Moh. Shofan, Pendidikan Berparadigma...,
}

secara sistematis. Persoalan pertama ini lebih bersifat filosofis, sedangkan yang kedua lebih bersifat metodologis, yaitu selain mampu menghadirkan konstruksi wacana pada dataran filosofis yang definite, landasan metodologi dalam proses integrasinya juga harus mapan sehingga bisa menyatu dalam sistem masyarakat muslim secara inherent dan komprehensif.

\section{Konsepsi Ontologis Pendidikan Islam; Hakikat dan Tujuan}

Pendidikan pada dasarnya merupakan suatu proses pengembangan diri dan kehidupan manusia secara utuh dan menyeluruh dalam berbagai bidang kehidupan sesuai dengan keberadaan manusia. Hal ini senada dengan apa yang dikatakan oleh Langeveld dalam buku yang ditulis oleh Kartini Kartono bahwa Pendidikan merupakan pencurahan daya dan upaya oleh manusia dewasa untuk membimbing generasi penerusnya yang belum dewasa menuju kedewasaan. ${ }^{17}$

Marimba juga merumuskan bahwa pendidikan adalah pembimbingan secara sadar oleh pendidik terhadap perkembangan peserta didik baik dari segi jasmani maupun rohani agar terbentuknya kepribadian yang utama. ${ }^{18}$ Artinya bahwa dalam upaya pendidikan ini harus didasari pada kesadaran akan sebuah tujuan yang ingin dicapai.

Hal ini kemudian dilegalisasi dalam Undang-Undang Sistem Pendidikan Nasional No. 20 Tahun 2003, bahwa Pendidikan didefinisikan sebagai suatu usaha sadar dan terencana untuk mewujudkan suasana belajar dan proses pembelajaran agar peserta didik secara aktif mengembangkan potensi dirinya untuk memiliki kekuatan spiritual keagamaan, pengendalian diri, kepribadian, kecerdasan, akhlak mulia, serta keterampilan yang diperlukan dirinya, masyarakat, bangsa dan negara. ${ }^{19}$

${ }^{17}$ Jamaluddin Idris, Kompilasi Pemikiran Pendidikan, (Yogyakarta: Suluh Press cet. ke-1, 2005), hlm. 147.

${ }^{18}$ Ahmad D. Marimba, Pengantar Filsafat Pendidikan Islam, (al-Ma'arif, Bandung, cet.ke-3, 1989), hlm. 19

${ }^{19}$ UU SISDIKNAS No. 20 Tahun 2003, Pasal 1 (1) 
Dalam pengertian yang lebih luas, pendidikan diartikan sebagai segala perbuatan atau usaha yang dilakukan oleh generasi tua untuk mentransfer pengetahuan, pengalaman, kecakapan, dan keterampilan kepada generasi muda. Hal ini dilakukan sebagai bentuk upaya persiapan generasi muda agar mampu menjalankan fungsi hidup mereka, jasmani dan juga rohani. ${ }^{20}$

Para Filsuf Pendidikan menyatakan bahwa pandangan seseorang tentang eksistensi manusia, baik sifat, karakteristik, maupun tujuannya, akan mempengaruhi rumusan pengertian pendidikan itu sendiri. Pandangan ini pula yang mendasari perbedaan aliran pendidikan seperti yang kita kenal saat ini, termasuk pandangan Islam terhadap pendidikan itu sendiri. ${ }^{21}$ Beragam kajian ontologis terhadap pendidikan Islam telah mengantarkan kita pada kesimpulan bahwa kajian ini tidak dapat dipisahkan dengan Sang Pencipta. Hakikat pendidikan Islam harus bersumber pada pandangan-pandangan yang didasarkan pada wahyu. ${ }^{22}$

Berdasarkan pandangan ini pula lah, dalam Islam, terminologi pendidikan mengenalkan tiga istilah, yaitu tarbiyah, ta'lim, dan ta'dib. Walaupun para ahli pendidikan Islam berbeda pendapat dalam menggunakan terma-terma tersebut, namun ketiga konsep ini, menurut Abdur Rahman Assegaf, saling mendukung antara satu sama lain dalam mendefinisikan hakikat pendidikan Islam itu sendiri. Dengan konsep ta'lim, peserta didik akan dihantarkan hingga memiliki nalar kognitif yang matang. Sedangkan dengan tarbiyah dan ta'dib peserta didik akan memiliki kematangan pada dimensi afektif dan psikomotorik. ${ }^{23}$ Menafikan salah satu term di atas, sama dengan mempersempit lingkup pendidikan Islam itu sendiri, sehingga

\footnotetext{
${ }^{20}$ Zuhairini, et al, Filsafat Pendidikan Islam, (Bumi Aksara, Jakarta, Cet. Ke-2, 1995), hlm. 2

${ }^{21}$ Hujair AH. Sanaky, Pembaharuan Pendidikan Islam Menuju Masyarakat Madani; Tinjauan Filosofis, http://www.sanaky.com/ 11 Oktober 2016.

${ }^{22}$ Ibid.

${ }^{23}$ Abdur Rahman Assegaf, Filsafat Pendidikan Islam, (Jakarta: Rajawali, 2011), hlm. 22
}

akhirnya tujuan pendidikan Islam untuk mewujudkan manusia yang mampu menjalankan tugasnya sebagai khalifah Allah yang mampu menggunakan dunia untuk tujuan akhirat sulit untuk terealisasikan.

Ahmad Tafsir dalam bukunya yang berjudul Ilmu Pendidikan Dalam Perspektif Islam mengutip definisi pendidikan Islam yang dikonsep oleh Ahmad D. Marimba bahwa pendidikan Islam adalah bimbingan jasmanirohani berdasarkan hukum-hukum agama Islam menuju terbentuknya kepribadian utama menurut ukuran Islam. ${ }^{24}$ Selanjutnya, Syahmin Zaini menyatakan bahwa pendidikan Islam adalah usaha mengembangkan fitrah manusia dengan ajaran Islam, agar terwujud kehidupan manusia yang makmur dan bahagia. ${ }^{25}$

Dengan demikian, terdapat keanekaragaman pandangan tentang pendidikan, namun dalam keanekaragaman tersebut terdapat titik-titik persamaan, yaitu suatu proses sadar di mana seorang yang dewasa berupaya mengarahkan pertumbuhan dan perkembangan seseorang lain yang belum dewasa, secara jasmani maupun rohani. ${ }^{26}$

Abdurrahman An-Nahlawi menyebutkan bahwa tujuan pendidikan Islam adalah sebuah pengejawantahan sikap pengabdian/ penghambaan kepada Allah sebagai manusia, baik sebagai individu maupun secara bagian dari sebuah sistem sosial. ${ }^{27}$ Lebih terperinci, Al-Abrasyi mengatakan bahwa tujuan akhir pendidikan Islam adalah Pembinaan akhlak, menyiapkan anak didik untuk hidup di dunia dan akhirat, penguasaan ilmu, dan keterampilan bekerja di masyarakat. ${ }^{28}$

Berdasarkan definisi dan tujuan pendidikan Islam yang dikemukakan para ahli di atas, dapat

\footnotetext{
${ }^{24}$ Ahmad Tafsir, Ilmu Pendidikan Dalam Perspektif Islam, (Bandung: Remaja Rosda Karya, 2005), hlm. 24

${ }^{25}$ Syahmin Zaini (1986), Prinsip-prinsip Dasar Konsepsi Pendidikan Islami, (Jakarta: Kalam Mulia 1986), hlm. 4

${ }^{26} \mathrm{Ibid}$.

${ }^{27}$ Abdurrahman an-Nahlawi, Pendidikan Islam di Rumah Sekolah dan Masyarakat, (Jakarta: Gema Insani Press, 1995), hlm. 117

${ }^{28}$ Chabib Thoha, Kapita Selekta Pendidikan Islam, (Yogyakarta: Pustaka Pelajar, 1996), hlm. 99
} 
disimpulkan bahwa pendidikan Islam tidak terbatas pada proses transfer pengetahuan maupun kecakapan semata. Lebih dari itu, Pendidikan Islam merupakan sistem pendidikan yang dibangun di atas dasar keimanan dan kesalehan, yaitu suatu sistem yang terhubung dengan Tuhan secara langsung. ${ }^{29}$

Lebih jauh lagi, pendidikan Islam sebagai suatu bagian dari pranata sosial juga terkait erat dengan pandangan Islam tentang eksistensi manusia. Pendidikan Islam berupaya untuk membangun pengertian dan kesadaran bahwa manusia memiliki posisi yang sama di depan Sang Pencipta. Hanya kadar dan kualitas ketaqwaan masing-masing manusia lah yang membedakan. ${ }^{30}$ Hujair Sanaky menyebutkan bahwa al Qur'an telah menggambarkan sifatsifat hakiki manusia yang berdampak pada tujuan dan cara pengarahan perkembangan manusia. ${ }^{31}$ Salah satunya implikasinya bagi pendidikan adalah bahwa manusia memiliki tanggung jawab dalam memikul amanah yang bersifat pribadi dan sebagai bagian dari kelompok sosial, artinya tindak tanduk yang dilakukan manusia merupakan tanggung jawab pribadi serta memiliki konsekuensi yang harus dihadapi, namun tanggung jawab ini juga berdampak pada lingkungannya.

Melalui perspektif ini dapat disimpulkan pula bahwa pendidikan bertujuan untuk mengarahkan dan mengembangkan segala kemampuan yang ada pada manusia semaksimal mungkin, sehingga ia berkembang menjadi seorang individu yang baik. ${ }^{32}$ Walaupun potensi manusia bisa berkembang di lingkungan secara mandiri, namun perkembangan potensi ini hanya bisa optimal dengan pengarahan orang lain. Oleh karena itu, pendidiklah yang bertugas untuk mengarahkan peserta didik agar ia dapat memikul amanah serta bertanggung jawab,

\footnotetext{
${ }^{29}$ Ahmad Tafsir, Ilmu Pendidikan Dalam Perspektif Islam, (Bandung: Remaja Rosda Karya, 2005), hlm. 24

${ }^{30}$ M.Rusli Karim, Pendidikan Islam Sebagai Upaya Pembebasan Manusia, dalam Buku: Pendidikan Islam di Indonesia antara Cita dan Fakta (ed. Muslih Usa), (Yogyakarta: Tiara Wacana, 1991) hlm. 29-32.

${ }^{31}$ Hujair AH. Sanaky, Pembaharuan Pendidikan... ${ }^{32}$ Ibid.
}

baik sebagai individu maupun sebagai bagian dari masyarakat, sesuai dengan profil manusia yang utama.

Sejak lahir manusia telah membawa berbagai potensi, seperti potensi keimanan, kecerdasan, memikul amanah, bertanggung jawab, maupun potensi lainnya. Semua Potensi ini lah yang menjadikan manusia mampu tumbuh secara aktif dan mampu berinteraksi dengan lingkungan. Kemudian, dengan arahan yang diberikan pendidik dapat diarahkan agar menjadi manusia muslim yang dapat mengemban tugas sebagai khalifah di muka bumi ini. ${ }^{33}$

Walaupun demikian, pendidikan Islam di Indonesia secara implementatif telah mengalami penyempitan makna. Pendidikan Islam tereduksi menjadi hanya pada pembelajaran materi keagamaan semata. Sehingga lembaga-lembaga pendidikan Islam di Indonesia belum mampu mengakomodasi luasnya lingkupan pendidikan Islam menurut al-Qur'an dan hadits yang seharusnya.

\section{Rekomendasi Alternatif Implementasi Pendidikan Islam Integratif di Lembaga Pendidikan}

Beragam permasalahan pendidikan Islam sebagaimana telah dibicarakan di atas, merupakan tantangan yang harus dipecahkan oleh ummat, terutama oleh lembaga pendidikan Islam. Selain penguatan landasan filosofis sebagai dasar pengembangan kelembagaan, maka implementasi atas konsep dan wacana pengintegrasian nilai-nilai ajaran Islam di lembaga pendidikan menjadi permasalahan tersendiri. Beragam tawaran alternatif implementasi pendidikan Islam terintegrasi ini telah dibangun oleh para cendekiawan muslim terhadap permasalahan ini.

Hal Pertama yang harus dilakukan setelah pembenahan landasan filosofis pendidikan Islam sebagaimana yang telah dibicarakan di atas adalah perlunya peninjauan kelembagaan terhadap fungsi lembaga pendidikan Islam yang ada. ${ }^{34}$

\footnotetext{
${ }^{33}$ Ibid.

${ }^{34}$ Jasin, Anwar, Kerangka Dasar Pembaharuan Pendidikan Islam; Tinjauan Filosofis, (Jakarta: tp, 1995),
} 
Lembaga pendidikan Islam di Indonesia saat ini direpresentasikan oleh pesantren, madrasah, dan sekolah Islam. Walaupun memiliki nama yang berbeda, namun menurut Ihsan dalam tulisan Arief Efendi yang berjudul Peran Strategis Lembaga Pendidikan Berbasis Islam di Indonesia, ketiga lembaga ini memiliki fungsi dan substansi yang dapat dikatakan sama. Secara fungsional, ketiga lembaga pendidikan ini menyatakan diri sebagai institusi pendidikan yang bertugas untuk membina fisik, mental, dan spritual peserta didik dan menyiapkan mereka menjadi generasi penerus yang berguna bagi bangsa dan agama. Sedangkan secara substantif, lembaga pendidikan ini dibangun atas dasar panggilan jiwa seorang kyai ataupun ustadz, baik secara perseorangan maupun kolegial yang tidak semata-mata bertujuan materiil, tapi sebagai bentuk pangabdian kepada Sang Pencipta. ${ }^{35}$

Dalam runutan sejarah, Pada awalnya Pendidikan Islam di Indonesia merupakan sebuah lembaga pendidikan tradisional. Proses pendidikan dilaksanakan atas dasar hubungan personal yang dijalin antara mubaligh atau dai dengan masyarakat sekitar dan dilaksanakan secara longgar. Kemudian, setelah masyarakat muslim terbangun dan meluas, pendidikan Islam secara intensif diselenggarakan di masjid atau langgar sebagai bentuk pendidikan non formal. Hingga akhirnya terbentuk lembagalembaga pendidikan formal, seperti pesantren, dan setelah abad ke-20 muncullah lembaga madarasah dan pendidikan tinggi Islam. Seluruh lembaga ini telah memberi sumbangan besar bagi proses penyebaran agama Islam di Indonesia.

Saat ini, perkembangan dan penyesuaian lembaga-lembaga pendidikan Islam dapat dikatakan cukup menyenangkan. Lembagalembaga pendidikan Islam saat ini telah menyesuaikan diri sebagai tempat untuk mempelajari ilmu umum dan ilmu agama. Walaupun demikian, adaptasi institusional ini

hlm. 5

${ }^{35}$ Efendi, A. Peran Strategis Lembaga Pendidikan Berbasis Islam di Indonesia, (Jurnal el Tarbawy No.I Volume 1, 2008), hlm. 3. masih dianggap sebagai bentuk peniruan dengan mengadopsi model pendidikan umum. Biasanya adopsi ini berupa pelaksanaan dua kurikulum "umum" dan "agama". Hal ini berdampak pada peningkatan beban kurikulum yang cukup berat dan terjadi tumpang tindih.

Jasin Anwar dalam tulisannya yang berjudul Kerangka Dasar Pembaharuan Islam; Tinjauan Filosofis, menyarankan sebuah solusi alternatif untuk mengatasi ambivalensi tujuan pendidikan Islam. Yaitu masing-masing lembaga pendidikan Islam harus memilih secara tegas satu di antara dua fungsi lembaga. Dua pilihan tersebut yaitu adalah: Pertama, mengembangkan desain model lembaga pendidikan umum yang terintegrasi dengan nilai-nilai ajaran Islam, serta handal dan mampu bersaing dengan lembaga pendidikan umum lain. atau pilihan kedua, fokus pada pengembangan desain pendidikan keagamaan yang berkualitas serta mampu mempersiapkan ahli-ahli di bidang agama. ${ }^{36}$

Lebih jauh lagi, di samping mengatasi ambivalensi tujuan kelembagaan, solusi alternatif yang dapat dilakukan oleh lembagalembaga pendidikan Islam adalah dengan mengatasi permasalahan kurikulum atau materi Pendidikan Islam yang selama ini sudah berjalan. Saat ini materi pendidikan Islam di lembaga pendidikan Islam masih terlalu di dominasi materi dan bahan ajar yang bersifat normatif eskatologis.

Materi dan bahan ajar ini kemudian disampaikan kepada peserta didik dengan semangat ortodoksi keagamaan. Artinya, peserta didik dipaksa patuh dan tunduk pada metanarasi-religius yang di ajarkan, tanpa diberi kesempatan untuk menelaah secara kritis. Materi pendidikan Islam yang diajarkan akhirnya menjadi kehilangan konteksnya terhadap kehidupan sehari-hari peserta didik. Kegiatan pembelajaran hanya menjadi aktivitas verbal dan formal untuk menyelesaikan materi ajar atau kurikulum yang diprogram dalam batas waktu yang telah ditentukan.

\footnotetext{
${ }^{36}$ Anwar Jasin, Kerangka Dasar ..., hlm. 15
} 
Untuk mengatasi permasalah tersebut di atas, maka lembaga pendidikan Islam harus mampu melakukan redesain kurikulum dengan mengintegrasikan nilai-nilai ajaran Islam ke dalam materi-materi ajar yang sudah ada. Ada beberapa alternatif yang bisa dilakukan oleh lembaga pendidikan dalam proses pengintegrasian kurikulum ini. Salah satu usaha integrasi ini dapat dilakukan dengan cara pemaduan mata pelajaran umum dan materi-materi Pendidikan Agama Islam.

Dalam hal ini kurikulum baik mata pelajaran Science seperti biologi, fisika, kimia, dan yang lainnya; maupun mata pelajaran sosial seperti sosiologi, antropologi dan lainnya dicoba untuk direkayasa ulang dengan memasukan konsep, teori dan nilai-nilai ajaran Islam, baik dalam komponen capaian pembelajaran, metode pembelajaran, materi ajar, media belajar, atau bentuk evaluasi pembelajaran.

Selanjutnya, model integrasi nilai-nilai Islam berikutnya adalah dalam bentuk pemaduan materi-materi keislaman dan materi-materi pelajaran umum. Hal ini dapat dilakukan dengan cara: Pertama, memasukkan materi-materi keislaman terkait dengan materi mata pelajaran umum baik pelajaran pengetahuan alam atau pengetahuan sosial guna perluasan pengetahuan peserta didik; kedua, memadukan konsep atau teori-teori ilmu umum ke dalam materi pelajaran agama Islam untuk memberikan wawasan keilmuan.

Terakhir, Pemaduan secara timbal balik antara materi pelajaran umum dan mata pelajaran agama dengan memperhatikan kesinambungan agar dapat menghindari tumpang tindih materi yang diberikan. Hal ini merupakan bentuk rancang bangun kurikulum yang menghubungkan teori-teori dan materi ilmu umum dengan ilmu agama agar terjadi hubungan saling mendukung dan memperkuat.

Model rekayasa kurikulum seperti ini sejalan dengan konsep islamisasi ilmu pengetahuan sebagaimana yang diperkenalkan oleh Ismail Raji' al-Faruqi dalam tulisannya yang berjudul Islamization of Knowledge: Problems, Principles and Prospective. Al Faruqi menyebutkan bahwa menjelaskan ada dua belas langkah atau tahapan yang harus dilakukan dalam rangka proses islamisasi ilmu pengetahuan.

Pada tahap pertama, Al Faruqi menyebutkan bahwa disiplin ilmu barat yang sudah sangat maju saat ini harus diurai berdasarkan kategori, prinsip, metodologi, problema dan tema. Penguraian ini harus dapat mencerminkan "daftar isi" sebuah buku pelajaran yang harus dikuasai oleh para siswa. Hasil uraian juga harus berbentuk kalimat-kalimat yang memperjelas istilah-istilah teknis, sehingga memperjelas makna kategori, prinsip, problema dan tema pokok disiplin-disiplin ilmu Barat dalam posisi puncaknya. ${ }^{37}$

Kedua, semua disiplin ilmu tersebut kemudian dikaji dan ditulis dalam bentuk bagan mengenai asal-usul dan sejarah perkembangan, pertumbuhan metodologis, perluasan wawasan, serta pemikiran yang telah dibangun oleh para tokoh utamanya. Langkah ini bertujuan memastikan pemahaman ummat Islam akan disiplin ilmu modern yang dikembangkan di Barat.

Langkah selanjutnya adalah Penguasaan khazanah Islam. Penguasaan khazanah Islam ini pun dilakukan dengan metode yang sama. Namun, apa yang diperlukan adalah khazanah pemikiran antologis terkait dengan disiplin ilmu. Kemudian pada tahap keempat, Al Faruqi menjelaskan bahwa khazanah Islam yang telah dikuasai masuk ke dalam tahap analisa. Dengan antologi-antologi yang telah disiapkan, khazanah pemikiran Islam harus dianalisa dari perspektif masalah-masalah kontemporer saat ini. ${ }^{38}$

Setelah khazanah pemikiran telah dianalisa, maka tahap selanjutnya adalah penentuan relevensi spesifik untuk setiap disiplin ilmu. Proses ini dapat dilakukan dengan mengajukan tiga pertanyaan mendasar, yaitu apa kontribusi

${ }^{37}$ Ismail Razi al Faruqi, Islamization of Knowledge: Problems, Principles and Prospective dalam Islam: Source and porpuse of knowledge (Proceedings \& Selected Papers of the Second Conference on Islamization of Knowledge 1402H/1982 AC), (International institute of Islamic Thought, 1998), hlm. 54

${ }^{38} \mathrm{Ibid}$, hlm. 55 
yang telah diberikan oleh Islam, mulai dari Al-Qur'an hingga para pemikir modernis, terhadap permasalahan yang dicakup dalam disiplin-disiplin ilmu moderen? Seberapa besar kontribusi Islam tersebut apabila dibandingkan dengan hasil yang telah diperoleh oleh disiplin ilmu tersebut? Dan apabila ada bidang masalah yang sedikit atau sama sekali tidak diperhatikan oleh khazanah Islam, maka ke arah mana kaum muslim harus memulai untuk mengisi kekurangan, melakukan reformulasi masalah, dan memperluas visi disiplin ilmu tersebut?

Setelah pertanyaan-pertanyaan tersebut telah dijawab, dan kedua sisi, yaitu khazanah Islam dan disiplin ilmu modern, sudah terekspos, maka tahap selanjutnya adalah penilaian kritis terhadap disiplin ilmu moderen dengan cara pandang Islam. Tahap ini merupakan bagian terpenting dalam proses islamisi ilmu pengetahuan, di mana tahap-tahap sebelumnya merupakan tahap-tahap persiapan. ${ }^{39}$

Tahap selanjutnya adalah langkah ketujuh, yaitu tahap penilaian kritis terhadap khazanah Islam. Sumbangan khazanah Islam yang berupa pemahaman umat Islam tentang kedua sumber agama, yaitu al Qur'an dan al Hadits, untuk setiap bidang kegiatan manusia harus dianalisa dan relevansi kontemporernya harus dirumuskan. Untuk melaksanakan tahap ini, maka tugas analisa kritis atas kontribusi nilai keislaman terhadap aspek-aspek kehidupan manusia harus dilakukan para ahli di bidang ilmu moderen yang mempelajari aspekaspek kehidupan tersebut. Kemudian hasil kajian ini kemudian dianalisa oleh mereka yang menguasai kedua sumber Islam ini, sehingga menjamin kemungkinan terciptanya pemahaman yang paling tepat.

Langkah kedelapan yang harus dilakukan kemudian adalah meninjau masalah-masalah utama umat Islam. Suatu studi sistematis harus dibuat tentang masalah-masalah politik, sosial ekonomi, inteltektual, kultural, moral dan spritual dari kaum muslim. Demikian pula selanjutnya dalam langkah kesembilan. Problem-problem umat manusia secara umum juga dilaksanakan.

\footnotetext{
${ }^{39} \mathrm{Ibid}, \mathrm{hlm} .57$
}

Masalah-masalah kemanusiaan dipetakan dan dianalisa di seluruh bidang kehidupan. ${ }^{40}$ Dengan kedua langkah ini, maka akan dihasilkan daftar permasalahan-permasalahan yang mencakup permasalahan utama kemanusiaan secara umum dan permasalahan utama umat Islam secara khusus.

Tahap selanjutnya adalah melakukan analisa kreatif dan sintesa. Pada langkah ini para cendekiawan muslim harus mampu melakukan sintesa antar kedua sumber keilmuan yang akan dipadukan, yaitu khazanah Islam dan disiplin ilmu modern. Langkah ini sebagai upaya untuk menutup jurang pemisah yang telah terbentuk selama berabad-abad. Pada langkah ini khazanah pemikiran Islam harus terhubung dengan capaian-capaian kontemporer, dan kemudian mendorong tapal batas pengetahuan ke horison yang jauh lebih luas dari pada yang sudah dicapai oleh disiplin-disiplin ilmu moderen. ${ }^{41}$

Terakhir, dua tahap yang harus dilakukan adalah merumuskan kembali disiplin-disiplin ilmu dalam kerangka kerja agama Islam dan kemudian dilakukan penyebar luasan ilmu pengetahuan tersebut dengan berbagai cara, baik dalam bentuk buku cetak, maupun lewat forumforum ilmiah. Dalam tahapan ini, al Faruqi menyadari bahwa ada kemungkinan perbedaan hasil pemikiran di kalangan ilmuwan-ilmuwan muslim dalam memberikan alternatif solusi atas permasalahan umat Islam dan kemanusiaan yang telah dipetakan pada tahap sebelumnya. Sebaliknya, perbedaan alternatif ini adalah bentuk kekayaan pemikiran umat Islam dan bentuk kesadaran atas masalah-masalah yang harus dipecahkan. ${ }^{42}$

Secara ringkas tahapan-tahapan yang dijelaskan oleh al Faruqi tersebut di atas, semuanya di lakukan dalam rangka untuk mencapai 5 tujuan utama islamisasi pengetahuan, yaitu:

a. Penguasaan pengetahuan-pengetahuan modern;

\footnotetext{
${ }^{40} \mathrm{Ibid}$, hlm. 58

${ }^{41}$ Ibid, hlm. 58 - 59

${ }^{42}$ Ibid, hlm. 61
} 
b. Penguasaan sumber-sumber pengetahuan Islam (al Qur'an dan al Hadits);

c. Membangun relevansi spesifik antara Islam dan semua area pengetahuan modern;

d. Mencari jalan untuk melakukan sintesis secara kreatif antara khazanah Islam dan pengetahuan modern; dan

e. Mengaplikasikan hasil pemikiran sesuai jalur yang ditetapkan dan akan memenuhi takdir ilahi. ${ }^{43}$

Oleh karena itu, sebagai konsekuensi apabila sebuah lembaga pendidikan Islam melakukan proses pengintegrasian keilmuan ini, maka lembaga-lembaga pendidikan tersebut harus menyediakan tenaga pendidik yang memiliki wawasan integrasi keilmuan ini, serta mampu mengimplementasikannya di ruang kelas secara mandiri. Namun, apabila hal ini belum memungkinkan maka lembaga dapat membuat tim ajar (team teaching) yang terdiri dari beberapa guru-guru dengan kompetensi yang berbeda, baik di bidang materi umum maupun materi agama Islam. Tim ajar ini bertugas untuk menyiapkan seluruh kebutuhan proses pembelajaran di ruang kelas, dari proses pengembangan kurikulum, capaian pembelajaran, bahan ajar, metode pembelajaran, sistem evaluasi, dan lain sebagainya.

Di sisi lain, lembaga pendidikan juga bertugas untuk mengembangkan lingkungan pendidikan yang islami. Setiap kegiatan peserta didik di lingkungan sekolah harus dikondisikan sedemikian rupa sesuai dengan nilai dan prinsip pendidikan Islam, sejak mereka masuk gerbang di hari pertama hingga mereka pulang dan menyelesaikan pendidikan mereka. Pengkondisian ini adalah upaya diharapkan akan berdampak pada perilaku peserta didik yang secara alami akan beradaptasi.

\section{PENUTUP}

Dari pembahasan di atas dapat disimpulkan bahwa dalam menghadapi perubahan masyarakat modern, secara internal pendidikan Islam harus menyelesaikan persoalan dikotomi, tujuan dan

\footnotetext{
${ }^{43} \mathrm{Ibid}, \mathrm{hlm} .53-54$.
}

fungsi lembaga pendidikan Islam, dan persoalan kurikulum atau materi yang sampai sekarang ini belum terselesaikan. Lembaga-lembaga pendidikan Islam harus menyiapkan desain baru pendidikan Islam terintegrasi. Maka, langkah-langkah redesain pendidikan Islam sebagaimana penulis paparkan di atas, dapat menjadi pertimbangan sebagai alternatif solusi permasalahan yang masih dapat kita rasakan saat ini. Redesain pendidikan Islam ini meliputi pengkajian ulang landasan filosofis pendidikan Islam dan hal-hal yang terkait, pengintegrasian nilai-nilai Islam ke dalam proses pembelajaran, serta metode implementasi hasil redesain tersebut.

Kajian-kajian antologi pendidikan Islam dapat dijadikan acuan untuk memperkuat landasan lembaga pendidikan Islam. Sedangkan pada tataran implementasi, integrasi pendidikan Islam dilaksanakan dalam seluruh sub-sistem pembelajaran, baik tujuan pembelajaran, materi, pendidik, maupun lingkungan.

Akhirnya, dengan melakukan desain pendidikan Islam, diharapkan lembaga-lembaga pendidikan Islam dapat meningkatkan kualitas pendidikannya agar memenuhi kebutuhankebutuhan masyarakat yang selalu berubahberubah. Lembaga-lembaga pendidikan Islami harus dapat memenuhi kebutuhan sumber daya manusia yang lebih handal, memiliki kompetensi untuk hidup bersama dalam ikatan masyarakat modern, serta memiliki pola fikir komprehensif dan integratif tanpa terlepas dari identitas mereka sebagai umat Islam. Wallahu A'lam bish-showab.

\section{REFERENSI}

Ancok, Djamaluddin, Membangun Kompotensi Manusia dalam Milenium Ke Tiga, Psikologika, Jurnal Pemikiran dan Penelitian Psikologi, Nomor: 6 Tahun III, (Yogyakarta: UII Press, 1998)

Anwar, Jasin, Kerangka Dasar Pembaharuan Pendidikan Islam; Tinjauan Filosofis, (Jakarta: tp, 1995)

Arifin, Muhammad, Kapita Selekta Pendidikan, (Jakarta: Bina Aksara, 1991) 
Assegaf, Abdur Rahman, Filsafat Pendidikan Islam, (Jakarta: Rajawali, 2011)

Azra, Azyumardi, Esei-esei Intelektual Muslim dan Pendidikan Islam (Jakarta: Logos Wacana Ilmu, 1998)

Azra, Azyumardi, Paradigma Baru Pendidikan Nasional, Rekontruksi dan Demokratisasi, (Jakarta : Kompas, 2006)

Efendi, A. Peran Strategis Lembaga Pendidikan Berbasis Islam di Indonesia, (Jurnal el Tarbawy No.I Volume 1, 2008)

Faruqi, Ismail Razi al, Islamization of Knowledge: Problems, Principles and Prospective dalam Islam: Source and porpuse of knowledge (Proceedings \& Selected Papers of the Second Conference on Islamization of Knowledge 1402H/1982 $A C$ ), (International institute of Islamic Thought, 1998)

Idris, Jamaluddin, Kompilasi Pemikiran Pendidikan, (Yogyakarta: Suluh Press cet. ke-1, 2005)

Karim, M. Rusli, Pendidikan Islam Sebagai Upaya Pembebasan Manusia, dalam Buku: Pendidikan Islam di Indonesia antara Cita dan Fakta (ed. Muslih Usa), (Yogyakarta: Tiara Wacana, 1991)

Khan, Ahmad Warid, Membebaskan Pendidikan Islam, (Yogyakarta: Wacana, 2002)

Kuntowijoyo, Paradigma Islam: Interpretasi Untuk Aksi (Bandung: Mizan, 1991)

Marimba, Ahmad D., Pengantar Filsafat Pendidikan Islam, (al-Ma'arif, Bandung, cet.ke-3, 1989)
Nahlawi, Abdurrahman, Pendidikan Islam di Rumah Sekolah dan Masyarakat, (Jakarta: Gema Insani Press, 1995)

Sanaky, Hujair, Pembaharuan Pendidikan Islam Menuju Masyarakat Madani; Tinjauan Filosofis, http://www.sanaky.com/ 11 Oktober 2016.

Sanaky, Hujair, Studi Pemikiran Pendidikan Islam Modern, http://www.sanaky.com/ diakses pada 11 Oktober 2016.

Shofan, Moh., Pendidikan Berparadigma Profetik; Upaya KonstruktifMembongkar Dikotomi Sistem Pendidikan Islam, (Yogyakarta; IRCISoD, 2004)

Tafsir, Ahmad, Ilmu Pendidikan Dalam Perspektif Islam, (Bandung: Remaja Rosda Karya, 2005)

Tafsir, Ahmad, Ilmu Pendidikan Dalam Perspektif Islam, (Bandung: Remaja Rosda Karya, 2005) Thoha, Chabib, Kapita Selekta Pendidikan Islam, (Yogyakarta: Pustaka Pelajar, 1996), hlm. 99

Usa, Muslih, Pendidikan Islam di Indonesia; Antara Cita dan Fakta, (Yogyakarta: Tiara Wacana, 1991)

UU SISDIKNAS No. 20 Tahun 2003, Pasal 1 (1)

Zaini, Syahmin, Prinsip-prinsip Dasar Konsepsi Pendidikan Islami, (Jakarta: Kalam Mulia 1986)

Zuhairini, et al, Filsafat Pendidikan Islam, (Bumi Aksara, Jakarta, Cet. Ke-2, 1995) 